\title{
On the Stem-Structure of Actinostemma biglandulosa.
}

BY

WILLIAM WALLACE, B.Sc. (St. And.).

With Plate XXXIV.

INTRODUCTION.

HE following are the main features of interest in the
anatomy of this stem :-

I. The vascular bundles are primarily collateral and remain so for a relatively long period. It is not until secondary thickening has made considerable progress within the bundles that these begin to acquire medullary phloem.

2. At the base of the older stem are a number of accessory bundles. These have a longitudinal course in the cortex and proceed from a meristem which has its origin in the endodermis.

The plant investigated was reared in one of the plant houses of the Royal Botanic Garden, Edinburgh. Belonging to the family Fevilleae-Gomphogyneae of the order Cucurbitaceae (Engler and Prantl), it is a tendriliferous liane with an annual stem, which, in its upper parts, is slender, cylindrical, and five-angled. A technical description of this species is given in Hooker's Icones Plantarum for 1899.

The primary structure, as seen in transverse sections of a young internode, shows the following arrangement of the vascular tissues (Pl. XXXIV, Fig. I). There are five outer

[Annals of Botany, Vol. XIV. No. LVI. December, I900.]

$\mathrm{U} \mathrm{u}$ 
bundles, each occupying a corner of the five-angled stem. Alternating with these corner bundles and more deeply seated are three larger bundles. On a casual examination these would appear to be the only bundles present at this early stage, namely five outer and three inner; but more careful inspection reveals that there are actually five inner bundles. The remaining two consist each of a few thinwalled, mostly narrow elements, of which those nearer the surface of the stem are differentiated as sieve-tubes with their companion-cells.

At first these bundles consist solely of phloem ; later they are collateral with xylem on the inside; finally they become bicollateral, like the rest of the bundles.

One of these imperfect bundles is thicker than the other ( $p$ and $p^{\prime}$ in Fig. I) and develops xylem sooner (Fig. 2). On approaching the node below, the stronger bundle gives off a branch which joins with other bundles to form one of the three large inner bundles of the internode next below, and then, diminished in thickness, proceeds downward through that internode of which it constitutes the thinner imperfect inner bundle. It seems probable that the two bundles just mentioned are the lower portions of leaf-traces: that the larger bundle seen in a transverse section is a trace of a lower leaf cut higher up in its course, while the smaller one is a trace of a higher leaf cut lower down.

\section{Medullary Phloem.}

Most Cucurbitaceae have bicollateral bundles: to this rule, however, the families Zanonieae, Fevilleae, and Gynostemmeae are exceptions ${ }^{1}$. The idea conveyed by the term bicollateral, invented by De Bary, is that of a bundle consisting of a mass of xylem between two masses of phloem, all the product of a single procambial meristem. Weiss ${ }^{2}$

1 Solereder, Syst. Anat. d. Dicotyledonen, p. 439, r898.

2 Scott and Brebner, 'On Internal Phloem,' Annals of Botany, vol. v, I $89 \mathrm{I}$, and works there cited. 
adopts this conception of bicollaterality, distinguishing medullary phloem from independent strands of phloem by means of the following characters :-

' $I$. The medullary phloem-strands in every case accompany the leaf-traces within which they lie, on their exit into the leaf.

2. They arise almost at the same time; or only slightly later than the parts of the phloem outside the xylem.

3. Where a cambium forms in connexion with them, it never produces wood also ${ }^{1}$.' On the other hand, Hérail ${ }^{2}$ declares that in the majority of plants with bicollateral bundles, the medullary phloem does not appear at the same time as the rest of the bundle, neither does it proceed from the same meristem. According to him it is only as applied to the bundles of the Cucurbitaceae that the term bicollateral is strictly appropriate; for in their case 'the internal phloem is as primary as the tracheae themselves.' Lamounette ${ }^{2}$ agrees with Hérail that the secondary origin of medullary phloem is the general rule, but denies that the Cucurbitaceae are exceptions to it. From observations of the apex of Bryonia dioica, this investigator concluded that the procambial meristem and the meristem which gives rise to medullary phloem are distinct from the first, the medullary phloem being a later development from those conjunctive tissue-cells which abut internally on the procambium.

In Bryonia dioica, according to Lamounette, the medullary phloem appears almost, but not quite at the same time as the rest of the bundle, and therefore at a point close beneath the growing point of the stem. The primary structure of the stems of species of Bryonia, Trichosanthes, Momordica, and Melothria was examined with reference to this particular. In all of them the vascular bundles at this early stage exhibited an abundant medullary as well as external phloem, of which the former was often greater in proportion.

In Actinostemma biglandulosa, however, the medullary

1 This distinction was shown by Scott and Brebner (op. cit.) to be invalid.

${ }^{2}$ Scott and Brebner, 'On Internal Phloem,' Annals of Botany, vol. v. 
phloem makes a late appearance and is never large in amount. The bundles of the seedling are unmistakably collateral (Figs. 7 and 8), as also are those of younger internodes of the older plant (Fig. 9). Sections of a stem over $\frac{1}{8}$ inch in diameter and a long distance from the apex showed no traces of differentiated medullary phloem (Fig. 9). It is not until a considerable amount of secondary tissue has been produced within the bundles that the elements of the medullary phloem proper to each begin to be differentiated. The appearance of the first sieve-tubes is preceded by the formation of a greater or less amount of small-celled meristem on the inside of the wood of each bundle (Fig. 9). This small-celled meristem arises by division of those cells which abut internally on the protoxylem. The primary sieve-tubes are differentiated at the inner limit of the meristem and form an irregular semicircle around the protoxylem: they are thus separated from the wood by one or more layers of meristem. The further increase in amount of the medullary phloem takes place by means of a medullary cambium formed in the following way:-Cells of the above-mentioned meristem, which lie on the outside of the first-formed sieve-tubes (i.e. nearer the wood), elongate in a direction which is radial with reference to a point occupying the centre of the protoxylem, and divide tangentially with reference to the same point. A somewhat fan-shaped arrangement of cells results (Fig. 10). The inner elements so formed pass over into phloem, but no centripetal wood is formed.

Medullary phloem does not arise simultaneously in relation to all the ten bundles of an internode. The three large inner bundles first acquire it ; then the larger of the remaining two inner bundles; next the corner bundles, i. e. those of the outer ring; and finally the remaining inner bundle, which, it will be remembered, was the last to develop its xylem (Figs. 2, 3, 4). As secondary thickening in the bundles proceeds, the more superficial layers of external phloem tend to become crushed against the resistant sclerenchyma. The medullary phloem, on the other hand, experiences no compression, 
since the cells of the fundamental tissue adjacent to it are active and make way for its increase. In the case of the large inner bundles this dilatation of the fundamental tissue surrounding them causes the compression of the pith and of the more central portions of the medullary rays.

As in other Cucurbitaceae ${ }^{1}$ secondary thickening is at first-confined to the bundles: the interfascicular cambium appears late and forms only parenchyma. The tension of the tissues thus set up ruptures the ring of sclerenchyma at points between the bundles, and cells insert themselves into the gaps and subsequently divide.

The bundles remain open throughout the life of the plant. While the normal cambium continues to function, additions are made to the medullary phloem by means of the medullary cambium. The medullary phloem in Actinostemma is small in amount as compared with the external phloem, and its sieve-tube elements have only about half the diameter.

Later on, phloem develops at the sides of the wood, which thus comes to be surrounded on all sides by that tissue ${ }^{2}$, as occurs in other Cucurbitaceae.

In Actinostemma the medullary phloem does not 'accompany the leaf-traces on their exit into the leaf' (contrast Weiss). Transverse sections of the older petiole showed collateral bundles. The medullary phloem accompanies the cotyledonary traces to their lower ends in the hypocotyl, where it stops. The tetrarch or triarch root has no pith and consequently no internal phloem. There is abundance of thin-walled parenchyma in the secondary wood of the root. A search was made for interxylary phloem, such as is described by Scott and Brebner (op. cit.) for the root of Thladiantha dubia, but none was found.

${ }^{1}$ De Bary, Comparative Anatomy, English edn., p. 328.

2 De Bary, Comparative Anatomy. 


\section{Accessory Bundles at the Base of the Stem.}

A number of accessory bundles are present at the base of the older stem. These begin a short distance above the hypocotyl and increase in thickness toward the base of that organ. They are visible externally as prominent ridges, especially on the hypocotyl, giving to transverse sections of this region a very sinuous outline (Fig. 5). The bundles run in the cortex, and there is usually one opposite each primary bundle. They follow the course of the cotyledonary trace-bundles in the hypocotyl, where there is one opposite each of the six bundles in the upper part, and one opposite each of the four bundles in the lower part. The meristem in which these new bundles appear is a product of the layer of cells which lies immediately outside the sclerenchyma. If, according to the statement in De Bary's text-book ${ }^{1}$, 'the ring of sclerenchyma (in Cucurbitaceae, \&c.) belongs to the plerome and marks its outer boundary,' then it is evident that we have to deal here with a meristematic endodermis of a cambial nature. In its earlier condition the same layer is differentiated as a starch-sheath, a fact supporting the above view of its morphological value. This starch-sheath is fairly well marked in transverse sections of the hypocotyl of the seedling (Fig. 6).

Opposite each primary bundle the cells of the endodermis elongate in a radial direction and divide tangentially, giving rise to rows of cells, not unlike periderm, which spread out in a radiate manner from each sclerenchyma-segment (Fig. 12). Between the sclerenchyma-segments, i.e. opposite the primary medullary rays, this formation is interrupted. From a certain number of radial rows a bundle is formed by some of the cells becoming converted into xylem-elements and others into phloem. Between xylem and external phloem the cells remain meristematic and function as a normal cambium, which adds to the thickness of the bundle in the usual manner. In time the wood comes to be surrounded more or less com-

1 De Bary, op. cit., p. 419. 
pletely by phloem, as occurs in the primary bundles. Primary and secondary bundles are connected at intervals by anastomoses which traverse obliquely the medullary rays.

My thanks are due to the Regius Keeper of the Royal Botanic Garden, Edinburgh, who kindly supplied the materials for this work, which, moreover, was done at the Laboratory of the Garden, under his supervision.

\section{EXPLANATION OF FIGURES IN PLATE XXXIV.}

\section{Illustrating Mr. Wallace's Paper on Actinostemma.}

Fig. I. Diagrammatic transverse section of a young internode, showing the arrangement and roughly the proportions of the vascular bundles. Xylem light, phloem dark.

Figs. 2, 3, 4. Diagrammatic transverse sections of stem at successively lower levels, illustrating the growth and differentiation of the various bundles.

Fig. 5. Diagrammatic transverse section of old hypocotyl, showing accessory bundles, of which there is one opposite each primary bundle. Shading as before : sclerenchyma brown.

Fig. 6. Portion of a transverse section of hypocotyl of seedling, showing one of four bundles. $E=$ starch-sheath or endodermis. The cells immediately within the starch-containing cells will become sclerenchyma. The circular dots are starch grains. $\times 90$.

Fig. 7. Portion of transverse section of stem of seedling, showing one of the three larger inner bundles in the primary condition. $p h=$ phloem, $p x=$ protoxylem, $c b=$ cambium, $P=$ fundamental tissue. $\times 35^{\circ}$.

Fig. 8. Portion of a transverse section of hypocotyl of seedling, showing the inner face of one of the six bundles. $p x=$ protoxylem, $P=$ fundamental tissue. $\times 35^{\circ}$.

Fig. 9. Portion of a transverse section of an internode about one-eighth inch in diameter, showing the small-celled meristem on the inner face of the wood of one of the three large inner bundles. $p x=$ protoxylem, $m=$ meristem, $P=$ fundamental tissue. $\times 35^{\circ}$.

Fig. Io. Portion of a transverse section of older hypocotyl, showing inner face of one of the six bundles. $p x=$ protoxylem, $p h=$ phloem, $m . c .=$ medullary cambium. $\times 350$.

Fig. II. Portion of a transverse section of stem a short distance above the insertion of the cotyledons, showing division of cells of the endodermis to form the meristem in which accessory bundles arise. $s=$ sclerenchyma, $E=$ endodermis. $\times 350$.

Fig. I 2. Portion of a transverse section of older stem above the insertion of the cotyledons, but at a lower level than the section of which Fig. II represents a portion; it shows the new bundles in the endodermis. $x=x y l e m, p h=$ phloem, $c=$ cambium, $m=$ medullary ray : all formed from the endodermis. $s=$ sclerenchyma, $p h=$ the position of the phloem of two primary bundles, $M R=$ medullary ray between them. $\times 90$. 
Annats of Botany
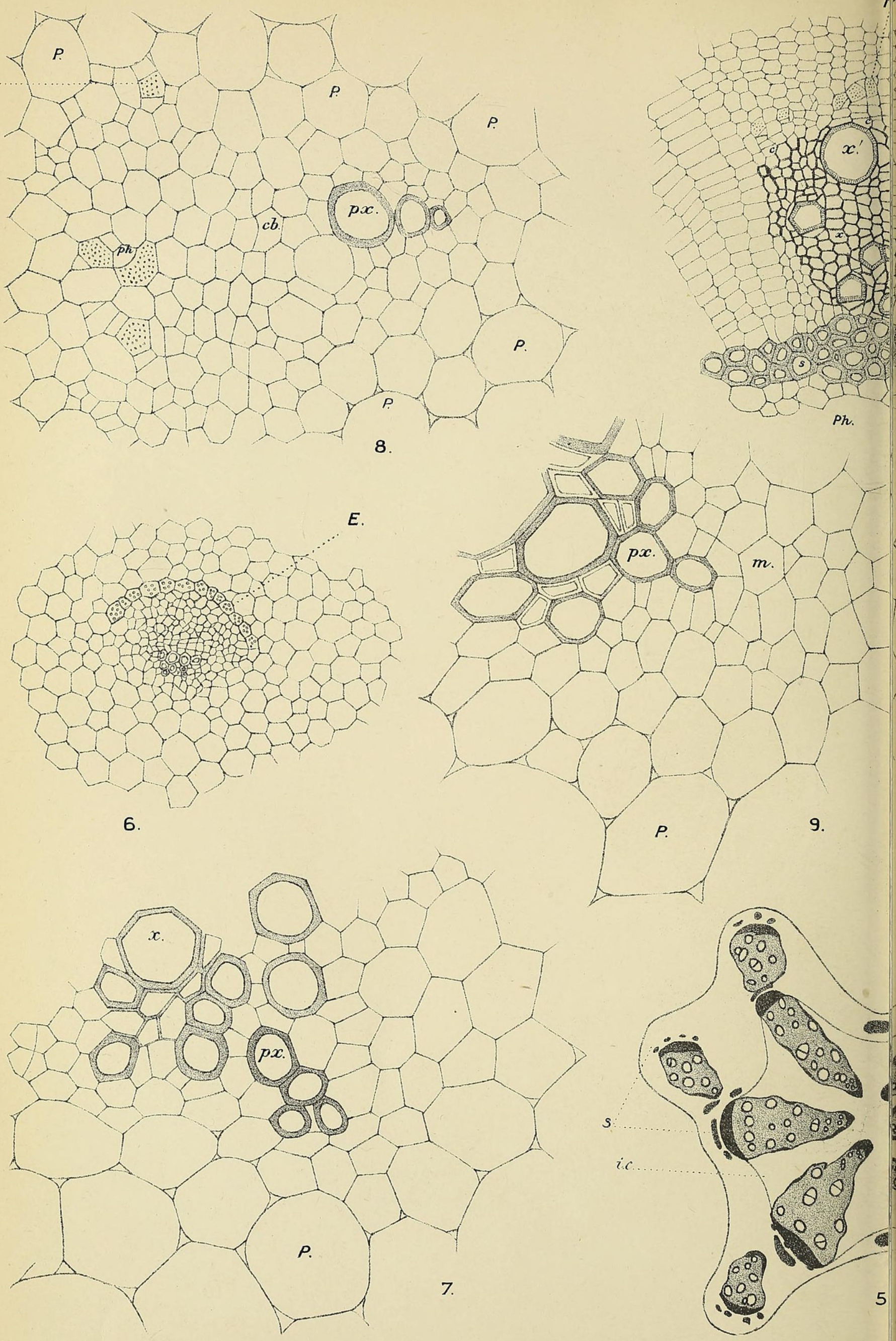

WALLACE. - ON ACTINOSTEMMA. 


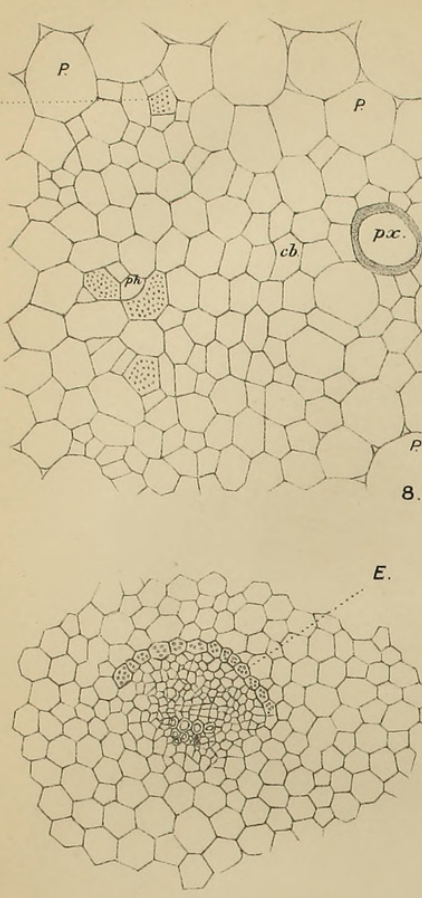

6.

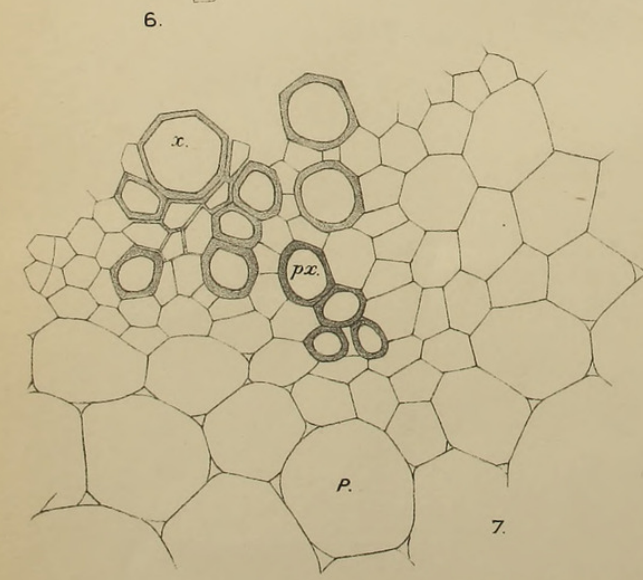

WALLACE - ON ACTINOSTEMMA

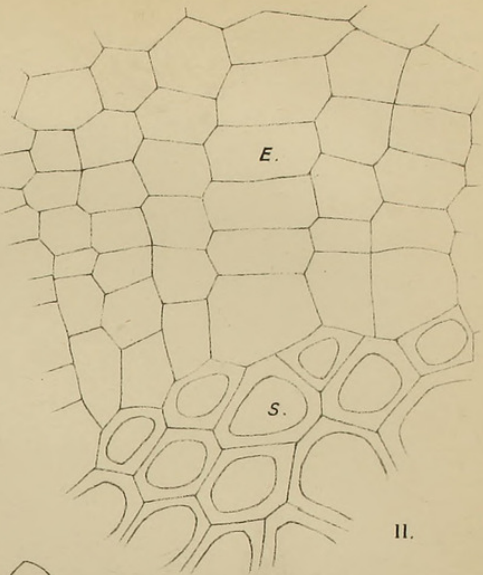

MR. 12.
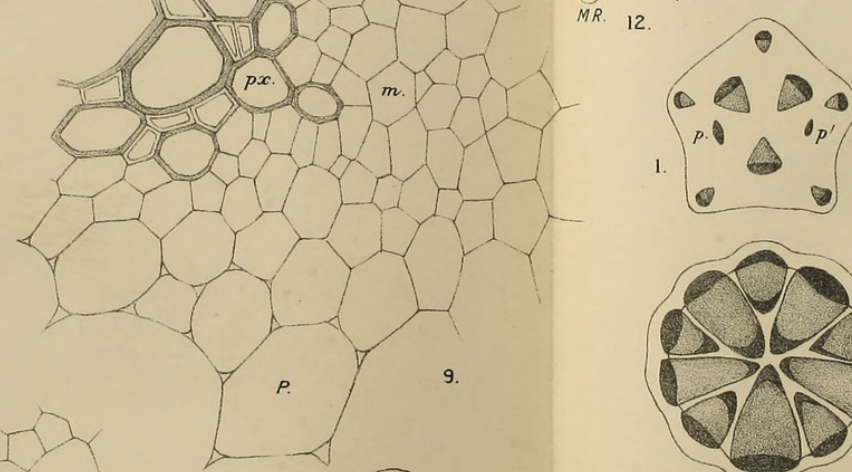

o) $x$

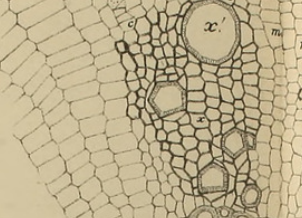

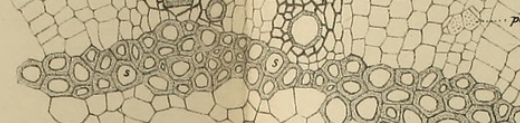

$P h$.
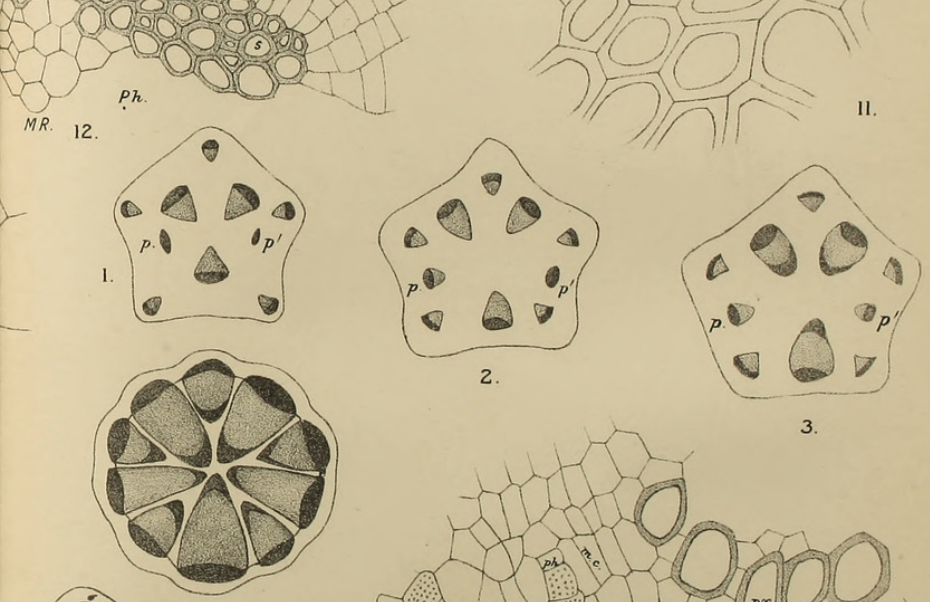

3.
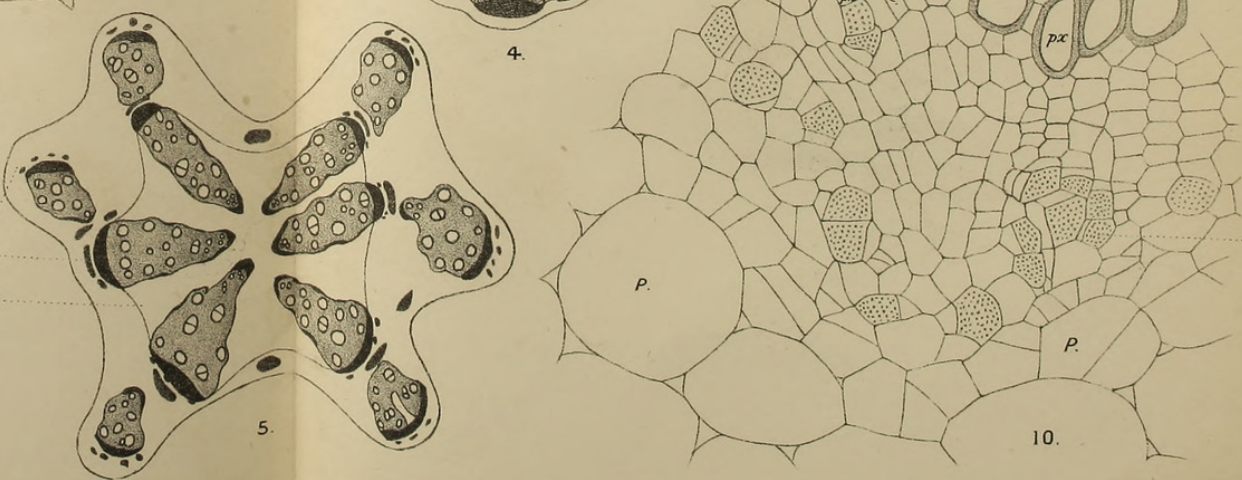

University Press, 0xford. 


\section{$2 \mathrm{BHL}$ Biodiversity Heritage Library}

Wallace, William. 1900. "On the stem-structure of Actinostemma biglandulosa." Annals of botany 14, 639-645. https://doi.org/10.1093/oxfordjournals.aob.a088797.

View This Item Online: https://www.biodiversitylibrary.org/item/238259

DOI: https://doi.org/10.1093/oxfordjournals.aob.a088797

Permalink: https://www.biodiversitylibrary.org/partpdf/318604

\section{Holding Institution}

Smithsonian Libraries

\section{Sponsored by}

Biodiversity Heritage Library

\section{Copyright \& Reuse}

Copyright Status: Not in copyright. The BHL knows of no copyright restrictions on this item.

This document was created from content at the Biodiversity Heritage Library, the world's largest open access digital library for biodiversity literature and archives. Visit BHL at https://www.biodiversitylibrary.org. 